\title{
AMERIKAI VÁLLALKOZÁSOKTATÁSI PÉLDÁK ADAPTÁCIÓJÁNAK LEHETŐSÉGE MAGYARORSZÁGON
}

Az elmúlt idôszakban számos hazai tanulmány, cikk számolt be külföldi (elsốsorban nyugati) vállalkozásoktatási tapasztalatokról (ld. Mihályi, 2001; Kiss, 2005). Az olyan publikációk azonban, melyek a külföldi tapasztalatok bemutatásán túl a hazai adaptálásról, illetve annak lehetôségéról számolnak be, hiányoznak. A szerző dolgozatában három amerikai egyetem vállalkozásoktatási módszereiról számol be; majd a vállalkozásoktatás helyzetének hazai felsốoktatási intézményekben való rövid bemutatását követốen azzal foglalkozik, hogyan tudják ezeket a módszereket az oktatásban hasznosítani a Budapesti Corvinus Egyetemen.

Kulcsszavak: vállalkozásoktatás, felsôoktatás, USA, Magyarország

A vállalkozásoktatás szerepe a múlt század második felében folyamatosan felértékelődött a világ fejlett országainak egyetemein. Azóta, hogy 1947-ben úttöróként a Harvard Business School meghirdette az első, nevében is vállalkozási tárgyat, az „Új vállalkozások menedzsmentjét" (Cruikshank, 2005), burjánzásnak indultak az ilyen kurzusok (Penaluna et al., 2006). Jól szemlélteti ezt a folyamatot az az adat is, hogy míg 1970-ben csupán 16 amerikai felsôoktatási intézmény kínálatában szerepeltek vállalkozási kurzusok, 1995-re ez a szám meghaladta a 400-at. 2000-ben pedig a felsőfokú képzéssel foglalkozó intézmények közül 1400 hirdetett ilyen tárgyakat (ISBA, 2004). A vállalkozói képzés felértékelődését jelzi, hogy ma már elképzelhetetlen az, hogy egy jó nevú egyetem kínálatában ne szerepeljenek vállalkozási kurzusok.

Ennek a folyamatnak a hátterében a megnövekedett kereslet áll. A világ fejlett országaiban a fiatalok egyre nagyobb része szerez felsőfokú végzettséget. Európában is egyre több friss diplomás kerül ki az iskolapadból úgy, hogy belátható idő́n belül nem talál állást. A kormányzatok erre megoldásként egyre többször - jobb alternatíva hiányában - a vállalkozói létet jelölik ki a diákok elé követendő útként, és vállalkozások alapítására ösztönzik óket (Matlay, 2005). A kisvállalkozás-politika az Európai Unióban (EU) egyre nagyobb szerepet kap, ugyanis míg a nagyvállalati szféra esetében jelentős alkalmazotti létszámnövekedés nem valószínúsíthetô, a kis- és középvállalati (KKV) szektor lehet a kulcs az unió munkanélküliségének felszámolásához (ld. Román, 2006). Ehhez az EU-országok vállalkozói aktivitásának növelését is el kell érni.

Mint azt a Global Entrepreneurship Monitor (GEM) konzorcium 2004-ben végzett felmérése is alátámasztja, az angolszász országok (kiemelten igaz ez az Egyesült Államokra) vállalkozói aktivitása rendre meghaladja, majd kétszerese Európa hasonló mutatójának ${ }^{1}$ (Szerb, 2005). Ez részben magyarázatot ad a térségek közötti növekedési különbségekre (ld. Horváth et al., 2007). Ezért az EU-országok közös érdeke a kisvállalkozói szektor fejlesztése, támogatása, mely az unió vállalkozáspolitikájában is megjelenik (ld. Csapó, 2007a).

A vállalkozói szemlélet és aktivitás erősítése Európa számára különösen fontos, hiszen a vállalkozói aktivitás és ezzel összefüggésben az újonnan alakuló cégek száma Európában hagyományosan alacsonyabb, mint az Egyesült Államokban (De, 2001). A vállalkozói lét presztízse az Egyesült Államokban mindig is nagyobb volt, mint Európában, ahol sokkal inkább kockázatos és bizonytalan cselekedetnek tekintették (és tekintik ma is) az önállósodást és saját cég indítását (European Commission, 2004b; Flash Eurobarometer, 2004). 
A Flash Eurobarometer (2002) felmérése szerint az európaiak sokkal kockázatkerülóbbek a tengerentúliaknál, ugyanis az európai válaszadók 44\%-a nem mer vállalkozásba kezdeni, ha felmerülhet a bukás kockázata. Az amerikai válaszadók között ez az arány csupán $29 \%$ volt. Európában messze többre tartják az alkalmazotti létet a vállalkozóinál $(51 \%$, illetve 45\%), ezzel szemben az Egyesült Államokban az eredmény éppen fordított (34\%, illetve 61\%) (Flash Eurobarometer, 2004). Az eltérésre részben választ adnak a kulturális különbségek: míg az óceán túloldalán a „tanulj hibáidból” eszme érvényesül, és pozitívan értékelik, hogyha valaki ugyan elbukik vállalkozásával, de tanulva tapasztalataiból újat indít, addig Európában „bukott vállalkozóként” megbélyegzik, és az újrakezdésre nem kap esélyt. Sốt, a jogszabályi keretek miatt ilyenkor sokszor minden vagyonát is elveszítheti. Az amerikai szemlélet az EU-ban is kezd lassanként meghonosodni, jó példa erre Németország, ahol egy újabb törvénymódosításnak köszönhetően a magáncsốddel kapcsolatos intézkedések többsége (a fizetésképtelenség bejelentése, a hitelezókkel való kötelezô egyeztetés, a bírósági eljárás) ingyenes a magánszemélyek számára. Ezzel a lehetôséggel a bajba került egyéni vállalkozók is élhetnek. Amerikában az oktatásban nagy hangsúlyt fektetnek a hallgatók kockázattúrő, kockázatvállaló képességének fejlesztésére, elfogadtatják velük, hogy nemcsak a pozitív példákból lehet tanulni (Csapó, 2007a).

A fentiek magyarázatot adnak arra, hogy vállalkozásoktatási programok fejlesztésekor miért az Egyesült Államokra tekint a legtöbb ország pozitív példaként. Cikkünkben a vállalkozásoktatás néhány kérdésének áttekintését követốen három amerikai egyetem vállalkozási programját mutatjuk be, arra fókuszálva, hogy mi ezekból az, amit a magyar gyakorlatba átültethetónek tartunk. Beszámolunk arról is, hogy eddig mit sikerült megvalósítanunk a Budapesti Corvinus Egyetemen, illetve milyen továbbfejlesztési lehetôségeket látunk.

\section{A vállalkozásoktatás legfóbb kérdése}

A szakirodalomban a mai napig visszatérô vitatéma, hogy vállalkozónak születni kell-e, vagy a vállalkozói létre nevelni is lehet. A vállalkozók többsége az első, míg az akadémiai, oktatói szféra az ezzel ellentétes, második álláspontot képviseli. Az oktatók - elismerve azt, hogy nem alkalmas mindenki vállalkozónak - azzal érvelnek, hogy hiába van meg valakiben rejtetten a vállalkozóvá válás képessége, ha olyan környezetbe, kultúrába kerül, ahol ez elsikkad. Ezeknek a rejtett vállalkozói képességeknek a felszínre hozásában látják az akadémiai szek- tor szerepének jelentőségét (Kuratko, 2003). Számos tanulmány számol be sikerról a vállalkozói létre nevelés, a vállalkozások indításának oktatás általi bátorítása terén (Gorman et al., 1997). A vállalkozásoktatás szerepét látszanak alátámasztani kutatások is: Davidsson (1995) a vállalkozásindítást befolyásoló tényezôket vizsgálva arra a következtetésre jutott, hogy az olyan jellemzók, mint a képzettség, szakmai ismeretek és tapasztalatok (azaz tanulható és fejleszthetô dolgok) legalább annyira befolyásolják azt, hogy valaki vállalkozó lesz-e, mint a velünk született személyes tulajdonságok.

A ,vállalkozónak csak születni lehet” álláspont képviselői is egyetértenek abban, hogy ezek a kurzusok, ha nem is nevelnek vállalkozót minden diákból, nagyon sok hasznos, praktikus, az élet bármely területén elhelyezkedve hasznosítható ismeretet megtanítanak. $\mathrm{Az}$ orák keretében megismert vállalkozói szemlélet a hallgatók mindennapi viselkedésére és magatartására is hatással van (Csapó, 2007b).

További vita tárgyát képezi, hogy ki oktasson. A vállalkozók szerint erre a feladatra csak olyan személyek alkalmasak, akik maguk is rendelkeznek jelentős vállalkozói tapasztalattal. Az akadémiai szféra ezt nem tartja kötelezőnek, bár elismeri, hogy szerencsés, ha az oktatónak magának is van vállalkozói tapasztalata. Abban egyetértenek a vállalkozókkal, hogy az oktatás sokkal hitelesebb, ha valaki a saját élményeit osztja meg a hallgatókkal. Ugyanakkor erre a feladatra a vállalkozókat sem mindig tartják alkalmasnak, hiszen ók általában pedagógiai gyakorlattal nem rendelkeznek, így gyakran megesik, hogy nem azokat az ismereteket adják át a hallgatóságnak, mely számukra a legfontosabb lenne. Köztes megoldásként terjedt el az a gyakorlat, hogy vendégelóadóként vállalkozók besegítenek az oktatásba, de moderálásukat, a tanulságok levonását és természetesen az órák szervezését továbbra is az oktatók végzik. Az oktatást a vállalkozókra azért sem lehet rábízni, mivel ók cégüket vezetik, és bármikor közbejöhet olyan probléma, melyet meg kell oldani. Olyankor pedig kevés vállalkozó tud nyugodt lelkiismerettel órát tartani, ha közben cége problémái lebegnek a szeme előtt.

\section{A vállalkozási kurzusok típusai}

A felsőoktatási intézmények kínálati palettáján megjelent számos vállalkozási kurzus/program jelentôs heterogenitást mutat. Egyesek csak elméleti ismeretek átadására törekszenek, mások már a vállalkozás elindítását ösztönzik, segítik; megint mások ezen is túlmutatnak, és már múködő vállalkozásoknak szólnak. Ezeket az eltéró kurzuscsoportokat hasonlítja össze az 1. táblázat (Jamieson, 1984). 
A vállalkozási kurzusok/programok fajtái

\begin{tabular}{|l|c|c|c|}
\hline & „Oktatás a vállalkozásokról” & „Oktatás a vállalkozásért” & „Oktatás a vállalkozásban” \\
\hline Oktatás tárgya & elméleti ismeretek & elméleti és gyakorlati ismeretek & gyakorlati ismeretek \\
\hline Alapvetó cél & vállalkozói lét megkedveltetése & vállalkozás elindításának segítése & $\begin{array}{c}\text { vállalkozás múködtetésének } \\
\text { segítése }\end{array}$ \\
\hline Célközönség & mindenki & vállalkozási lét iránt érdeklő́ók & vállalkozók \\
\hline Oktatási módszerek & elméleti kurzusok & $\begin{array}{c}\text { elméleti kurzusok, szimulált, } \\
\text { illetve valós vállalkozások }\end{array}$ & mentorálás, coaching \\
\hline Jellemzó tantárgyak & $\begin{array}{c}\text { vállalkozási alapismeretek, } \\
\text { kisvállalati politika }\end{array}$ & $\begin{array}{c}\text { üzleti tervezés, vállalkozások } \\
\text { menedzsmentje }\end{array}$ & $\begin{array}{c}\text { finanszírozáskeresés, szellemi } \\
\text { termékek védelme }\end{array}$ \\
\hline
\end{tabular}

Forrás: Saját szerkesztés Jamieson (1984) nyomán

Az elsố csoportba a vállalkozásokról oktató, elsősorban elméleti kurzusok tartoznak. Ezek is többfélék lehetnek: ide tartoznak egyfelől az egyre népszerúbb vállalkozási alapismereteket oktató, alapozó, kedvcsináló tárgyak, melyek egyrészt azt túzték ki célul, hogy azok a hallgatók is megismerjék a vállalkozások világát, akik tudják magukról, hogy sosem fognak saját céget alapítani. Másrészt céljuk, hogy a hallgatók figyelmét felkeltsék a vállalkozási téma iránt, és arra motiválják ốket, hogy vegyenek fel további tantárgyakat, illetve kezdjenek el saját vállalkozás alapításán gondolkodni. A tantárgyak másik csoportja (mint például a vállalkozások a gazdaságban, regionális gazdaságtan, vállalkozáspolitika) arra képez, hogyan kell „törődni” a vállalkozásokkal, melyek a szektor jellegzetességei. Ezek a kurzusok azoknak szólnak, akik a késốbbiekben a vállalkozások világában nem mint vállalkozók, hanem mint gazdaságpolitikai döntéshozók lehetnek érintettek.

Az „oktatás a vállalkozásért” programok célja a vállalkozásalapításra való ösztönzés, ezért már mind elméleti, mind pedig gyakorlati tudás átadását felvállalják. Az elóbbire példák a finanszírozási, üzleti tervezési tantárgyak, ahol a hallgatók még elsősorban olyan elméleti ismereteket szereznek, melyet késóbb a gyakorlatban is hasznosítani tudnak. A programok másik csoportja a szimulált vagy valós vállalkozásokon keresztüli oktatás. Ilyen például a középfokú oktatásban a Junior Achievement diákvállalkozási, vagy a felsôoktatásban a Budapesti Corvinus Egyetem (BCE) „Hallgatói Spin off modell" (HSM) programja ${ }^{2}$.

$\mathrm{Az}$ „oktatás a vállalkozásban” kategóriába sorolt programok már ezen is túlmennek, és már ténylegesen létezô vállalkozások vezetối (a vállalkozók) számára hirdetik meg ốket. Alapvetô céljuk, hogy segítsenek a vállalkozás növekedési pályára állításában. A cél ugyanis nem a csupán az alapítót és szúkebb környezetét eltartani képes ún. „életmód-vállalkozás” (ld. Timmons et al., 2007) létrehozása, hanem egy olyan cégé, mely számos munkahelyet teremt, adót fizet, így hozzájárul a gazdaság fejlődéséhez. Az ilyen cégek létrehozásában a gazdaságpolitikusok is érdekeltek, hiszen mint Szerb László és szerzôtársai is írják, ,,az új vállalkozások nagy száma önmagában nem garancia a dinamikus gazdasági növekedésre, a mennyiségnél sokszor fontosabb a minőség" (Szerb et al., 2004: 680. o.). Idetartoznak például a finanszírozással (elsősorban üzleti angyal és kockázati tókés befektetők keresésében segítő) és a szellemi termékek védelmében segítő tárgyak.

\section{Nyugati példák}

A következôkben az Egyesült Államok egyetemein szerzett tapasztalatainkról számolunk be, azokra az aspektusokra koncentrálva, melyek véleményünk szerint sikerrel lehetnének átültethetók a hazai gyakorlatba. Az elmúlt év során három amerikai egyetem vállalkozásoktatási programjával ismerkedhettek meg kollégáink, melyek a Pennsylvania State University (PSU), a Harvard Business School (HBS) és a UC Berkeley. Míg az elsô egyetemen a mi képzésünknek megfelelố 3. évfolyamos diákok számára meghirdetett kurzusokat ismertünk meg, a Harvard és Berkley inkább az MBA-szintû́ vállalkozási kurzusai bemutatását tartotta fontosnak. Az ilyen MBA-képzésekre általában már komoly szakmai tapasztalattal rendelkezó hallgatók jönnek, akiknek a gyakorlati tudásukra alapozhatnak az oktatás során.

\section{Vállalkozásoktatás a Pennsylvania State Universityn}

\section{Csapatmunka, verseny}

A PSU-n a „Technológiai alapú vállalkozások” (Technology Based Entrepreneurship) kurzus keretein belül a kreativitás mellett nagy hangsúly helyeződik a csoportos munkára: a félév során 2-3 hetes idôszakon- 
ként új feladatokat kell teljesíteniük a hallgatói csapatoknak. A csoportmunkát, a kommunikációs képességeket azzal is fejlesztik, hogy gyakran nem egy-egy egymást már ismeró baráti kör áll össze a félév során a feladatok teljesítésére, hanem az oktató válogatja össze a csoportokat. Sớt, minden feladatnak újonnan kialakított csoportok vágnak neki, ezzel a hallgatók új kapcsolatokat építenek, megismerik egymás gondolkodását, ötleteit, szakmai hátterét. Így elkerülhetô az, hogy valaki egy szorgalmasabb csapathoz csatlakozva a félévet minimális munkával teljesítse, és az is, hogy egy gyengébb összetételú csoport a szemeszter során végig „,vesztesen kerüljön ki” minden feladatból, ezzel tagjai gyorsan elveszítsék motivációjukat. Minden feladat versenyfeladat. Az értékelést sokszor az üzleti szférából érkező sikeres vállalkozók, menedzserek, kockázati tốkések végzik, akik saját vállalkozói tapasztalataik, befektetôii preferenciáik alapján döntenek. A félév végi érdemjegyet döntô mértékben az alakítja ki, hogyan teljesítenek egymáshoz képest a hallgatók. A diákok ezt az osztályozási módot korrektnek tartják, hiszen tudják, hogy a való életben is a jobbak, az ügyesebbek érvényesülnek. Ezért mindent megtesznek a magasabb pontok megszerzésének érdekében.

\section{Futurisztikus ürjármú, kreatív ötletek}

A kurzusok teljesítésekor nagyon sok gyakorlati - valódi életból származó - feladattal szembesülnek a diákok. A hallgatók kreativitásának fejlesztésére az egyik legjobb feladat az, melynek keretében értéktelen, használaton kívüli, hulladék eszközöket kellett összegyújteniük, ezekból valamilyen terméket készíteniük, majd ezt értékesíteniük. Az a csapat nyer, amelyik a legtöbb pénzt keresi ezzel. Érdekes módon a hallgatókban fel sem merül, hogy a könnyebb végén fogják meg a dolgot, és tehetôs szülőket, barátokat kérjenek meg termékeik magas áron való megvásárlására. Nagyon komolyan veszik a versenyt, mindent megtesznek a győzelemért. Ha mégis veszítenek, akkor igyekeznek társaik példájából és saját hibáikból tanulni. Termékeiket a helybelieknek próbálják eladni: forgalmas helyen kiállítják, majd az arra járóknak kínálgatják eladásra. Készült már így futurisztikus ürjármú és vízi jármú is.

\section{Miból lesz a cserebogár...}

A félév másik kedvelt feladata, hogy három hét alatt saját termék vagy szolgáltatás értékesítésével tegyenek szert minél nagyobb nyereségre a csapatok. Az egyenlő esélyek biztosításához minden csapat 50 dollárt kapott az oktatótól, ezt a kezdeti befektetést kellett megsokszorozniuk. A diákok kreatív ötletekkel álltak elô: az egyik csoport húsvét előtt tojás alakú csokit és süteményeket készített; mások saját készítésú egyetemi emléktárgyakat (az egyetem nevezetes pontjairól készült bekeretezett fotókat) készítettek és árultak. Volt olyan csapat, amelyik az egyetemi focicsapat sztárjainak fényképét értékesítve próbálta a versenyt megnyerni. A legsikeresebb csapat „PowerHourDVD” nevú termékkel lépett piacra: internetról legálisan letölthetô videokliprészletekból készítettek egy egyórás DVDfilmet, melynek célja a bulik előtti hangulat fokozása: amikor a DVD egy újabb számra vált, a nézóknek inniuk kell - ezzel elég gyorsan emelkedetté válik a hangulat. A DVD-k darabját 5 dollárért árulták, előállítási költségük (a saját munkát nem számítva) kevesebb, mint egy dollár volt. A termék iránti kereslet a hallgatók minden korábbi elképzelését felülmúlta: az egyetemi kollégiumokban, ahol árulták ezeket, akkora tetszést arattak, hogy minden 5. diák vett belólük. Így 5 nap alatt (a többi idő a konstrukció kitalálására és a lemezek legyártására ment el) közel 1500 dollárt kerestek vele. Volt még csapat, amelyik házibuli, mások középiskolás diákok számára hétvégi programok szervezésével próbáltak bevételre szert tenni. Ezek az ötletek hosszú távon valószínúleg sikeresek lettek volna, azonban az idő rövidsége miatt kevés alkalmuk volt ilyen programmal előállni - ezért a bevételük is kevesebb lett.

\section{Hallgatóból vállalkozó, vállalkozóból milliomos}

Persze a hallgatók is tudják, hogy egy-egy ilyen háziverseny megnyerése még nem garancia arra, hogy az életben is ilyen sikeresek lesznek. Néhány évvel korábban a kurzust hallgatta és vett részt ebben a versenyben az a diák is, akinek az ötlete a kurzus keretében ugyan nem végzett a legjobbak között, ma mégis egy közel hárommillió dollárt érô vállalkozás tulajdonosa. Társával az az ötletük támadt, hogy milyen hasznos lenne, ha az USA-ban oly népszerú platós pick-up kisteherautókhoz különféle platófedeleket gyártanának, amelyek lehetôséget biztosítanak a plató többcélú hasznosítására (például szerszámok tárolására, egyéb eszközök szállítására). Amerika a hatalmas méretek földje (minden jóval nagyobb, mint Európában), ezért nem meglepó, hogy a legfelkapottabb termékük napjaikban az a platófedő, amire egyszerre két quaddal is fel lehet hajtani, és így lehet szállítani ezeket. A hallgató diplomája megszerzését követôen nem alkalmazottként helyezkedett el, hanem belevágott a kurzus keretében felmerült ötlete megvalósításába. Az ötlet olyan jónak bizonyult, hogy 3 év elegendó volt vállalkozása felfuttatására: jelenleg a legtöbb amerikai nagyvárosban van viszontértékesítő partnere, és a nemzetközi terjeszkedésen gondolkodik. 


\section{A Harvard Business School vállalkozásoktatási gyakorlata}

Mint a bevezetốben is írtuk, az elsô egyetemi vállalkozási kurzust a Harvard Business Schoolon hirdették meg 1947-ben. A vállalkozási tárgyak jelentősége az érdeklődésnek köszönhetôen azóta tovább nőtt. A végzett hallgatók körében végzett felmérések azt mutatták, hogy a diploma megszerzését követő öt éven belül egyre többen kezdenek saját vállalkozásba, vagy valamilyen más, vállalkozásokkal foglalkozó területen (elsôsorban kockázati tốkés cégnél) helyezkednek el. Erre válaszként az MBA-programjuk kötelező tárgyává tették az „Entrepreneurial Management” címú vállalkozási kurzust.

A Harvard szakította „vállalkozó” szó hagyományos jelentésével, a gazdasági funkciót, illetve tevékenységet ellátó személlyel való azonosítás helyett az egyfajta irányítási magatartást, szemléletet felmutató egyént jelenti (HBS, 2006). Ezért a hangsúlyt az oktatásban nem a vállalkozás megalapításáig terjedő folyamatra, hanem a szervezet múködtetésére helyezik. A vállalkozást egy soha véget nem érô folyamatnak tekintik, mely az ötlet (lehetôség) felismerésétól az erőforrások megszerzésén, a lehetőség kihasználásán keresztül a betakarításig, illetve újrakezdésig tart.

A Harvardon a vállalkozást hármas kontextusban tárgyalják, mint azt az 1. ábra is mutatja. Egyrészt a kiindulási tényezók szerepére hívják fel a figyelmet, melyek nélkül elképzelhetetlen a vállalkozás. Ezek az üzleti lehetóségek, melyet az emberek felismernek, illetve kedvező környezet esetén megvalósítanak, és ezzel megszületik az üzlet.

\section{A vállalkozás fogalmi kerete a HBS szerint}

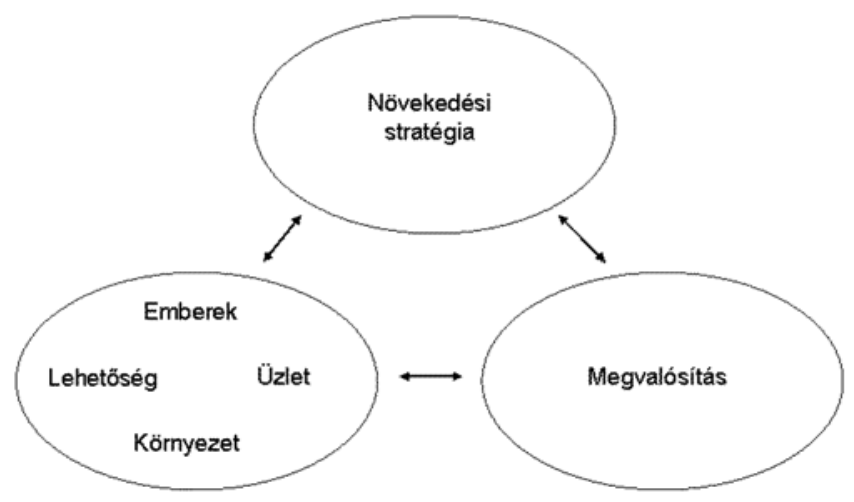

Forrás: saját szerkesztés Vecsenyi (2006a) alapján

A második vizsgált kontextus a növekedési stratégia kialakítása. Hallgatóikat gyors növekedésú, gazellacégek létrehozására ösztönzik, ehhez pedig alapvető fontosságú stratégiai tervek készítése a lehetőségek megragadására, az erőforrások (munkatársak, finanszírozási forrás) megszerzéséhez. A harmadik kontextust a növekedési stratégia kialakítását követô megvalósítás jelenti, azaz a tervekben leírtak véghezvitele. Az 1. ábrán szereplő három összetevő egymással szorosan öszszefügg, külön-külön nem értelmezhetőek, a sikerhez mindhárom léte szükséges.

A kurzusok középpontjában ennek a három tényezőnek a tárgyalása áll. A növekedési stratégiával összefüggésben az eróforrások (tốke) megszerzésére fókuszálnak, mivel a gyorsan növekvố vállalkozások egyik legnagyobb kihívását a gyors felfutáshoz szükséges források megszerzése jelenti. Ezért a kurzusok kiemelten foglalkoznak a forrásbevonás módszertanával, elsősorban üzleti angyal- és kockázatitóke-befektetókre gondolva. Ezzel azt - a magyar vállalkozók számára sokszor idegen - gondolatot ültetik a hallgatóik fejébe, hogy „használd más erőforrását”3. Azaz arra tanítanak, hogyan lehet megvalósítani egy olyan üzleti lehetôséget, amelyhez a vállalkozónak nem áll rendelkezésre elegendô erôforrása.

Magyarországon idegennek hat a Harvard oktatóinak az az iránymutatása, hogy nyer-nyer szituációk megteremtésére kell törekedni. Előfordulhat, hogy egy-egy helyzetben a vállalkozónak lehetősége van üzlettársát kihasználni, azonban ez negatívan hat a hoszszú távú üzleti kapcsolatra, így megbosszulhatja magát. Tapasztalatunk szerint hazánkban ez a szemlélet sokszor nem érvényesül, nálunk ehelyett a „,dögöljön meg a szomszéd tehene is" hozzáállás a jellemzô, azaz, ha nekem nem lehet hasznom valamiból, akkor a szomszédnak se legyen.

A Harvard Business School elsôsorban MBA-programjáról híres, mely képzésre már komoly szakmai tapasztalattal rendelkező hallgatók jönnek. Az órák során erre a gyakorlati tudásra alapozhatnak az oktatók, ezért elsôsorban az esettanulmány módszerre támaszkodnak, melynek az az üzenete, hogy „,minden üzleti helyzet mögött van egy lehetôség" (Cruikshank, 2005: 230. o.). A hallgatók a hagyományos oktatás keretében azt várják el, hogy a tanár megmondja a helyes megoldást a problémára. Ezzel szemben az esettanulmány megoldása során egészen más a cél, a feladat a „tudom, hogy nem vagy minden információ birtokában, de az esetben leírtakra támaszkodva te hogyan döntenél?" kérdés megválaszolása. A tanulás folyamata a következó: az esettanulmányokból egyénileg készülnek fel a hallgatók, majd ezt kiscsoportban megvitatják. Ezt követôen dolgozza fel az esetet az egész tankör közösen egy vezető oktató moderálásával. A tanár csak facilitálja az eseményeket: „tudom, hogy nem én vagyok a legoko- 
sabb, azért vagyok, hogy benneteket moderáljalak". Az órákon, melyre az oktatók nem ritkán több órát készülnek, akkor is, ha már számtalanszor tanították az esetet, a profizmus érvényesül. A nagy hallgatói létszám miatt gyakori megoldás, hogy egy idóben, párhuzamosan, több szeminárium is fut egy-egy tárgyból. Ekkor alapvető elvárás, hogy az egyes oktatók tematikái, az órák felépítése között minimális legyen a különbség.

Az elmélet és gyakorlat összekapcsolásának egyik módja, hogy a hallgatókat gyakran küldik ki vállalkozásokhoz, ahol egy-egy projektet kell megoldaniuk csoportosan. Máskor a vállalkozókat hívják meg az órákra. A vendégelőadók azonban nem szabadon tartanak elöadást arról, amirôl kedvük van, hanem irányított kérdésekre válaszolnak, az oktató moderálja óket. Az órán a hallgatók is aktívan részt vesznek, ez szinte mindig beszámít az érdemjegybe. Az órai munka értékelésében segít, hogy a szemeszter során minden diák mindig ugyanott ül, előtte áll névtáblán nagy betúkkkel a neve. A tanár igyekszik minden hallgatójából már az első órára felkészülni, ezt segíti, hogy mindenkiról részletes személyes bemutatkozó szöveget kap (Vecsenyi, 2006a).

A Harvard Business School sikerének egyik kulcsa ma már a mögötte levố 65.000 fős alumni, melynek tagjai szívesen gondolnak vissza egyetemistaéveikre, és közöttük hihetetlen nagy az összetartás. Aktív kapcsolatot tartanak fenn a HBS-sel, szívesen veszik, ha cégeik történetéról esettanulmányok készülnek az oktatás számára, melyet az oktatásban hasznosítanak, még akkor is, ha ezek valamilyen sikertelenségról, kudarcról számolnak be. Cégeik örömmel fogadnak hallgatókat egy-egy projekt megoldására, így nem az egyetemnek kell ilyen hallgatói feladatok után mennie, hanem megkeresések érkeznek hozzájuk.

\section{A UC Berkeley technológiaalapú vállalkozásokra fókuszáló képzése}

A UC Berkeley ${ }^{3}$ vállalkozási programjának fejlődésének irányát alapvetôen befolyásolta az egyetem földrajzi elhelyezkedése: a high-tech cégeket vonzó Szilícium-völgy kapujában magától értetődő volt, hogy olyan programot kell kialakítani, mely egyrészt segít a technológiaalapú cégek elindításában, másrészt építhet a már meglevő vállalkozások nyújtotta elônyökre. A Berkeley vállalkozásoktatását alapvetóen ez a technológiai fókusz különbözteti meg a másik két, korábban bemutatott egyetemtól. Az alapok sokban megegyeznek, így a PSU-hoz és a HBS-hez hasonlóan a Berkeley programja is nagy hangsúlyt fektet az üzleti lehetőség felismerésére, illetve a megvalósításhoz szükséges eróforrások megszerzésére. A vállalkozást ennek megfe- lelően olyan tevékenységként definiálják, mely nem más, mint egy „olyan lehetôség megragadása, melyhez az erőforrások jelenleg nem állnak rendelkezésünkre" (Stevenson - Gumpert, 1985). A vállalkozás tehát nem egyenlő a kisvállalati menedzsmenttel, hanem olyan tevékenységekról szól, melyek pillanatnyilag ugyan kisvállalati keretek között valósulnak meg, de ezek a cégek szerencsés esetben nagyon gyorsan nagyok lesznek. Nagyra törô lehetôségek megragadásáról szól, melynek során gyakran nemcsak valamely új technológián alapuló termék vagy szolgáltatás fejlesztése és piaci bevezetése a cél, hanem sokszor az igazi kihívást az jelenti, hogy a piacot is meg kell teremteni ehhez (Engel et al., 2006a).

A vállalkozás egy folyamat, melyet elemezni, megérteni, és az arra fogékony hallgatóság számára tanítani lehet. A Berkeley oktatói is osztják azt az álláspontot, hogy csak abból lehet vállalkozót faragni, akiben megvan ennek a csírája. Az oktatás szükségessége abban rejlik, hogy segít ezeket a képességeket a felszínre hozni, ezáltal növeli a vállalkozói karrier választásának valószínúségét. A vállalkozói siker valószínúsége is növelhető azáltal, hogy azokat is oktathatják, akik nem lesznek ugyan vállalkozók, de vállalkozásokkal foglalkoznak mint tanácsadók, könyvelók, ügyvédek, befektetési bankárok vagy kockázati tókések. Az órák keretében ók is megismerik a vállalkozási folyamatot, és megértik, milyen kihívásokkal szembesülnek a vállalkozók. Így amikor kapcsolatba kerülnek vállalkozótársaikkal, sokkal nagyobb a valószínúsége annak, hogy mindkét felet elégedettséggel eltöltő üzletet sikerül kötni (Engel et al., 2006a).

A vállalkozási folyamat-ahogy a Berkeleyn oktatják - egy szükséglet felfedezésével indul, melyre valamely termék vagy szolgáltatás megoldást jelent. Ha ennek létezik vagy megteremthetố a piaca, amelyen nyereséggel értékesíthetô, akkor érdemes belevágni ebbe az üzleti lehetőségbe. Ahhoz, hogy ennek a terméknek/ szolgáltatásnak az értékesítésére alapozva a létrehozandó vállalkozás sikeres legyen, szükség van valamilyen versenyelónyre, amely lehet know-how, szabadalom, személyes kapcsolatok, fogyasztókkal való bánásmód ismerete, terjesztési tapasztalat stb. Mivel a Berkeleyn elsősorban az új technológiákra alapozott vállalkozási ötletekre fókuszálnak, ezért a következő lépést a prototípus készítése jelenti. Legkésóbb ekkor el kell készíteni egy üzleti tervet, melynek kiemelten kell foglalkoznia a piaci bevezetés kérdésével, és azzal, hogy milyen erőforrásokra van szükség. Az üzleti terv alapul szolgál ezeknek a kritikus eróforrásoknak (elsôsorban a tốkének és az alkalmazottaknak) a megszerzéséhez. Miután ezeket sikerült teljesíteni, akkor indulhat a termék/szol- 
gáltatás elő́llítása és a piaci bevezetése. Ha kiderül, hogy a vállalkozási ötlet átütô siker, akkor sincs vége a folyamatnak, ugyanis a versenyelőny megôrzéséhez és a piacon maradáshoz elengedhetetlen a vevókkel való folyamatos kapcsolattartás, a velük való jó kapcsolat kialakítása. A piacon végbemenő trendeket is nyomon kell kísérni, meg kell érteni a változásokat, és igazodni kell az új kihívásokhoz.

Míg a Harvard nagy előnye az alumniban rejlik, addig a Berkeley esetében a Szilikon-völgy közelsége jelenti ezt. Az elméleti oktatás könnyen összekapcsolható a gyakorlattal: egyrészt vállalkozókat, gyakorlati szakembereket vonnak be az oktatásba, másrészt az oktatással foglalkozó egyetemi szervezeti egység köré számos olyan gyakorlatias programot építettek, mely a hallgatók készségeit fejlesztheti. A legfontosabbak a következók:

ABerkeleynek is van üzletiterv-versenye, de amivel kiemelkedik a többi intézmény közül, az az, hogy nekik nemcsak a hagyományos cégekre kialakított versenyük van, hanem külön megmérettethetik magukat a napjainkban egyre inkább terjedó gondolatot hordozó szociális vállalkozások ${ }^{4}$. A zsúriben üzleti angyalok és kockázati tókések is helyet kapnak. A hallgatók motivációját növeli a jó szereplésre, hogy a legjobbak befektetést is szerezhetnek egyúttal ötletük megvalósításához.

$\mathrm{Az}$ egyetem egy alacsony költséggel fenntartható inkubátorszolgáltatást is kínál az induló cégek számára: ez nem más, mint egy nagyobb irodahelyiség egyik épületük aljában, ahol egy kommunikációs eszközökkel (internetre kötött számítógép, telefon, fax) felszerelt terem és tárgyalók állnak rendelkezésre. Tanácsokért az oktatókhoz fordulhatnak a hallgatók, így ezzel a megoldással a költségeket alacsonyan lehet tartani. A múlt tapasztalatai alapján évente átlagosan 20 start-up cég alakul a vállalkozásoktatásért felelős Lester Center környékén. A legjelentősebbek között van a tevékenységét Keyhole néven megkezdô cég, melyet a Google néhány éve felvásárolt, és azóta a Google Earth szolgáltatás alapját képezi. Az Inktomi internetes keresésre szakosodott vállalkozást pedig a Yahoo találta megvásárlásra érdemesnek, és fejlesztéseit beépítette saját keresőszolgáltatásába.
Az üzletiterv-versenyek és az inkubátorszolgáltatás mellett számos olyan kezdeményezés van, mely összehozza az üzleti és az egyetemi szférát. Ilyen az immár 16 éve múködő vállalkozói klub, mely eseményeken a hallgatók ismerkedhetnek meg sikeres környékbeli vállalkozókkal, tanulhatnak tapasztalataikból. A Harvardhoz hasonlóan a kurzusok keretein belül különbözô vállalkozásoknál töltenek rövidebb-hosszabb idôt a hallgatók, és dolgoznak különféle projekteken.

A vállalkozásoktatási program bázisa egy alapozó tárgy, melyet minden érdeklődônek el kell végeznie. Ezt követốen választhatnak a hallgatók 5 alapvetố területhez tartozó kurzusokból (ld. 2. ábra). A tárgykínálat jellemzője, hogy sokkal részletesebben tárgyalnak egyegy témakört, mint nálunk Magyarországon, így külön tárgy keretében foglalkoznak a hallgatók az üzleti lehetôség azonosításával, illetve a kockázati és magántôkével is külön kurzus keretében ismerkedhetnek meg.

2. ábra

A UC Berkeley vállalkozásikurzus-kínálata

Szak alaptárgyai (gazdasági, mérnöki stb)

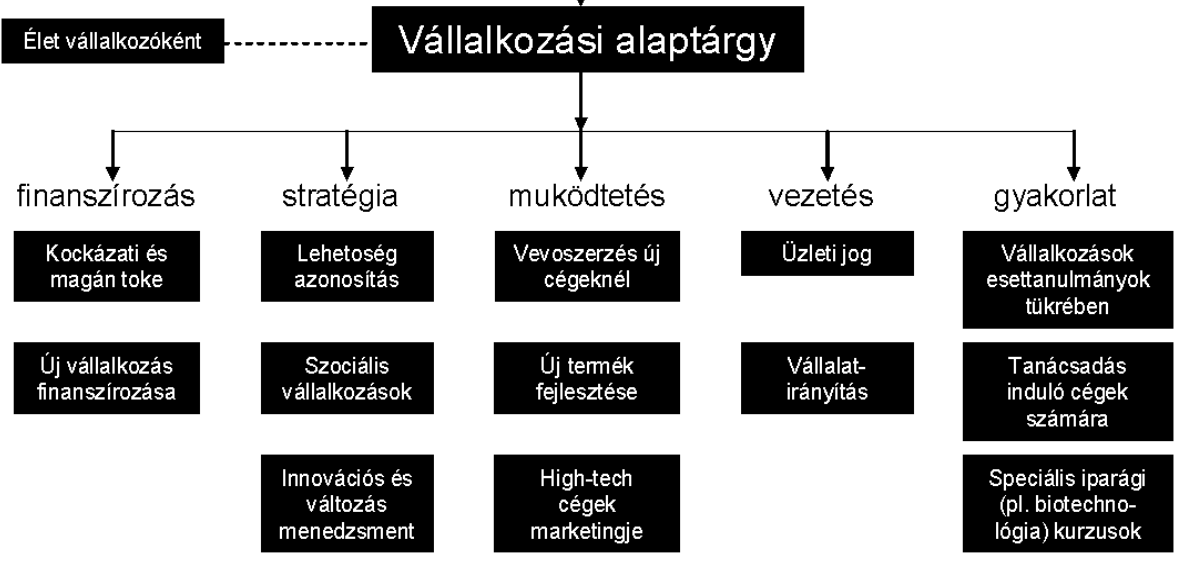

Forrás: Engel et al. (2006b)

\section{A vállalkozásoktatás helyzete Magyarországon}

Mielôtt rátérünk a fentiekben bemutatott külföldi példák magyarországi adaptációjának lehetôségeire, rövid áttekintést adunk a vállalkozásoktatás helyzetéról a hazai fóiskolákon és egyetemeken.

Napjainkra a vezetố hazai felsőoktatási intézmények többségében elérhetőek a vállalkozói kurzusok a hallgatók egyre szélesebb köre számára (ld. Szerb - Márkus, 2006; Román, 2006). Ezt mutatja a „Collegiate Entrepreneurship" kutatás keretében a magyar egye- 
temek között végzett felmérés is. A 3. ábrán egyrészt egyetemek szerint, másrészt tudományterületek szerint láthatjuk a vállalkozói kurzusok látogatási arányát. Ez alapján megállapítható, hogy a gazdasági képzésekben részt vevô hallgatók helyzete a legjobb, közülük hallgattak legnagyobb arányban ilyen kurzust.

\section{Az amerikai példák alkalmazása a Budapesti Corvinus Egyetemen}

A Berkeley gyakorlatához hasonlóan néhány évvel ezelőtt a BCE-n is meghirdettek a hallgatók széles köre számára egy vállalkozói alapozó tárgyat, a Kisvállalko-

A vállalkozói kurzusok látogatási aránya a magyar egyetemeken, ill. szakcsoport szerinti bontásban (\%)

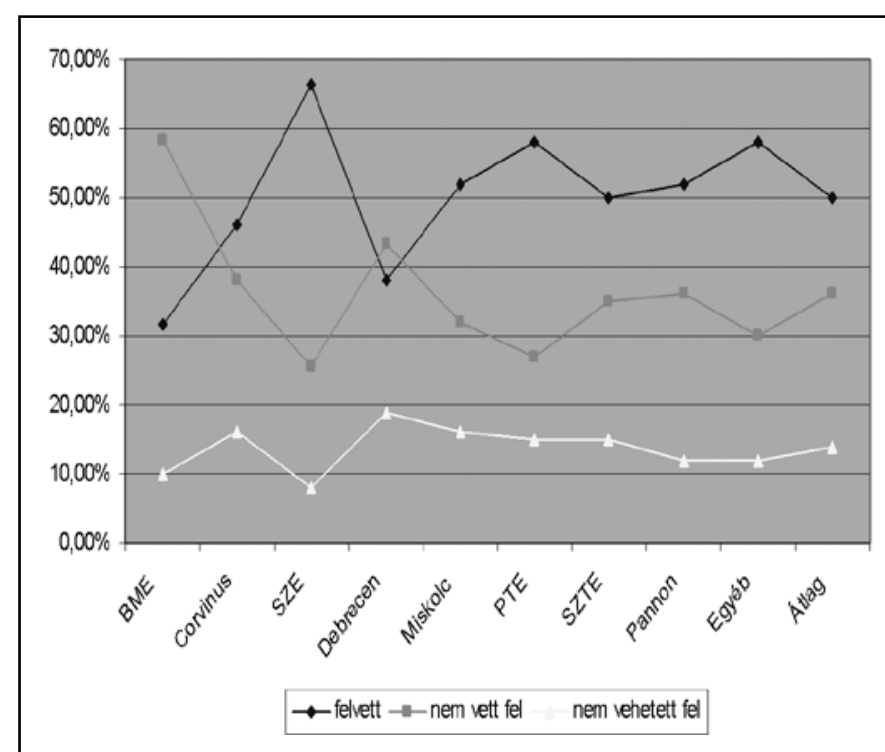

Forrás: Szerb et al. (2006: 28. o.)

A kutatás hasonló eredményeket mutat, mint amelyeket korábban Román Zoltán (2006) publikált. Román Zoltán is a magyar felsőoktatási intézményeket vizsgálva megállapítja, hogy a gazdasági karok a vállalkozásokról alapismereteket mindenhol nyújtanak valamilyen kötelezô tárgy (leggyakrabban az elsôsorban nagyvállalati gazdálkodással foglalkozó vállalati gazdaságtan) keretében. A hallgatók többsége azonban nem gazdasági képzésben tanul. Ezeket a karokat Román a következő három csoportba osztja aszerint, hogy:

1. nem érzékelik vagy elutasítják az igényt a vállalkozási ismeretek nyújtására,

2. vállalkozási alapismereteket adnak rövid, kötelezô vagy választható tárgy keretében,

3. bóvebb vállalkozási ismereteket is nyújtanak kötelező (és választható) tárgyak keretében.

A karok kisebb része (elsôsorban a múszaki képzést nyújtók) tartoznak csak a harmadik csoportba, így a vállalkozásoktatás terén még jelentős fejlesztési lehetôségek előtt áll a hazai felsőoktatási intézmények többsége. A külföldi gyakorlat számos olyan elemet tartalmaz, melyek hazánkban is sikerrel alkalmazhatóak. Ezeket a következókben a Budapesti Corvinus Egyetem példáján mutatjuk be.

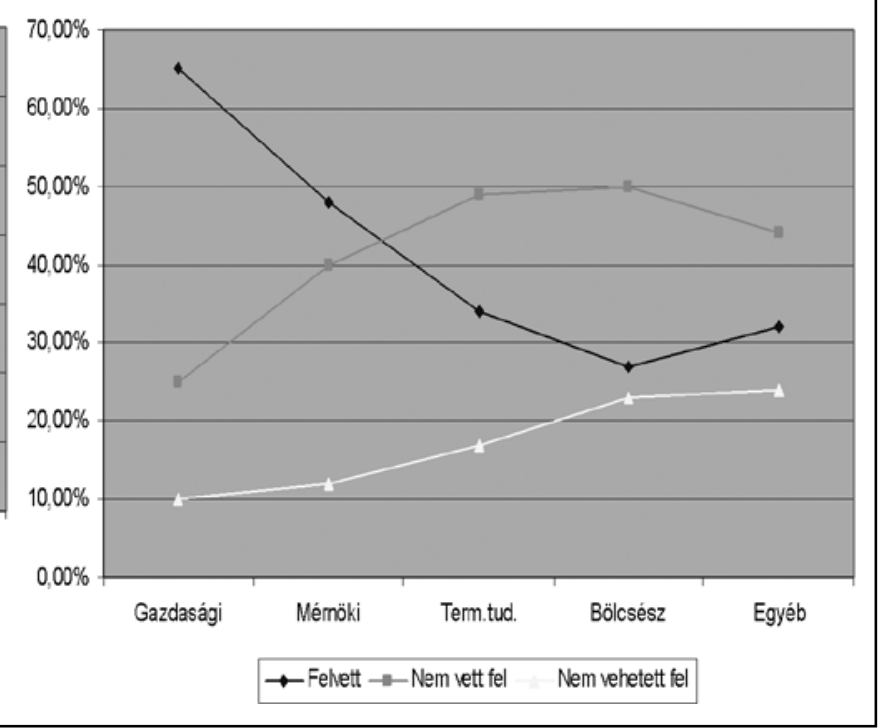

zások indítása és múködtetése címmel, melynek célja az, hogy minél több hallgatót ismertessen meg a vállalkozások világával, keltse fel az érdeklődést a vállalkozói lét iránt. A kurzus iránti érdeklődés a várakozásokat meszszemenően felülmúlta, ezért az első alkalommal 160 fős létszámkeretet folyamatosan emelni kellett, a kurzust így az elmúlt években már 350 hallgató veszi fel tanrendjébe. Elsősorban ez az a tárgy, ahol a Kisvállalkozás-fejlesztési Központ (KFK) oktatói a hallgatók szélesebb körével találkoznak, ezért ennek keretében van leginkább lehetőség széles körben újítások kipróbálására.

Érdekes tapasztalat volt, hogy az egymás mellett ülő hallgatók nem ismerik egymást, úgy ülnek le, hogy a szomszédoknak be sem mutatkoznak. Sôt, egymás neveit nem tanulják meg a félév végére sem. Így a kurzus fontos hozadékától, a személyes kapcsolatrendszerük fejlesztésének lehetôségétől esnek el. Ez pedig sokszor jól jöhetne számukra, ugyanis a bemutatkozásokkal rendre kiderül, hogy számos diák családjában van vállalkozás, és ezek akár egymás üzleti partnerei is lehetnének. Erre a Harvardon látott módszerek jelentették a megoldást: egyrészt mindenki kapott egy kétoldalú névtáblát, melyet az asztalra maga elé kellett helyeznie, ezzel segítette azt, hogy mind az oktatók, mind a diáktársai is megismerjék és a nevén szólíthassák. Először 
nemtetszés fogadta azt a Harvardról átvett gyakorlatot is, hogy mindenki azonos helyen üljön a félév során, de ezt néhány óra után megszokták.

Bár vállalkozási kurzusra jelentkeztek a hallgatók, a félév elején az volt tapasztalható, hogy jelentôs részük inkább hagyományos órát várt, és nem vette természetesnek, hogy az órához hozzá kell járulnia. Ennek leküzdésére játékos gyakorlatok keretében történtek próbálkozások. Az elsố órán például minden hallgatónak le kellett rajzolnia azt, ami a vállalkozó szó hallatán eszébe jutott, majd ezt a képet hallgatótársainak bemutatni. Ez is segített a feloldódásban. Ahol lehetséges volt, a többi óra elején is rövid, pár perces jégtörố játékokkal indítottak az oktató kollégák.

Az elmélet és gyakorlat összekapcsolására az előadásokra vállalkozókat hívnak meg. De attól a más tantárgyak esetében elterjedt gyakorlattól eltéróen, miszerint a külsố elóadó beszél az egész óra során, ezzel mintegy mentesíti az oktatót, a vállalkozók az óra keretében csak egy-egy 25-30 perces blokkot kapnak, és az előadók irányított kérdések alapján számolnak be saját tapasztalataikról. Az előadó közben felhívja a hallgatóság figyelmét egy-egy fontosabb elhangzott gondolatra. Ez a fajta együttmúködés lényegesen nagyobb felkészülést kíván mind az oktatótól, mind a vendégelőadótól, hiszen az oktató nem az órán találkozik elôször a vállalkozó slide-jaival, hanem együtt készülnek fel az órára, ami akár több órás közös munkát is igényelhet.

A kisvállalkozói fó szakirány kurzusai keretében már nagyobb önállóságra, más irányú feladatok végzésére is van lehetőség a kisebb, 35 fős létszámnak köszönhetôen. A félév eleji, szervezetfejlesztố trénerek által szervezett, többnapos csapatépítố tréninget követôen immár mindenki ismeri egymást, így a szervezeti ellenállás is kisebb. Az egyik innovatív módszer az oktatásban a PSU-val közösen meghirdetett Nemzetközi üzleti tervezés (International Business Planning) c. tárgy keretében valósul meg. A kurzust mindkét egyetemról 15-15 diák hallgatja. A hallgatóknak nemzetközi csoportokban különböző valós vállalkozási projekteken kell a félév során dolgozniuk, az eredményeket a szemeszter végén prezentálniuk. Az innovativitás abban rejlik, hogy az órák egy része videokonferenciákon keresztül zajlik, a két egyetem oktatói felváltva vezetik a szemináriumokat. A hallgatók közben a projekteken dolgoznak mind az óra keretében (ezt a gyakorlatot szintén az amerikai egyetemekról vettük át, ugyanis a hallgatói csoportok egyik legnagyobb problémája az órán kívüli találkozás megszervezése [Csapó, 2007c], így viszont tanár által felügyelt körülmények között tudnak együttmúködni), mind ezen kívül, amennyiben a feladat jellege miatt (pl. utánjárást igényel) ez nem megoldható.
A vállalkozások menedzsmentje kurzus óráin sikeres vállalkozók adják át tapasztalataikat a hallgatóságnak, állítanak pozitív példát saját életútjuk bemutatásával. A kurzus fókuszában a vállalkozók vannak, beszámolóikhoz az elméleti órák adnak fogalmi keretet. Az egyetemen megszokott tárgyaktól eltéróen itt nem a tankönyvekból elsajátítható elméleti tudást kell a hallgatóknak hasznosítaniuk, hanem éppen ellenkezóleg, a megismert esetekból, gyakorlatból kell általánosítást levonniuk, és egy esszé formájában megfogalmazniuk, melyek voltak azok a gondolatok, melyeket a vállalkozóktól tanultak, és maguk is alkalmazni tudnak.

A Berkeleyhez és a Harvardhoz hasonlóan a Kisvállalkozás-fejlesztési Központ is felismerte a külsô környezet szerepét, ezért olyan programokat, kapcsolatokat igyekszik kialakítani, melyek az oktatásban is hasznosíthatóak. Ennek egyik eleme a „Hallgatói Spin-off Modell" néven meghirdetett program, ami egyfajta „üzletépítő verseny”. Ez a hagyományos üzletiterv-versenyeken annyiban túlmutat, hogy itt nem az elméleten, hanem a gyakorlaton van a hangsúly. A program keretében a legjobb üzleti ötlettel és hozzá tartozó egyszerúsített üzleti tervvel pályázó hallgatók anyagi támogatást is kapnak vállalkozásuk elindításához, de ami ennél fontosabb, minden cég kap egy-egy tapasztalt mentort, aki gyakorlati tanáccsal látja el ôket (ld. bővebben: Szirmai - Csapó, 2006, illetve Csapó, 2007b). Az elbírálásnál az ötlet és az eltökéltség a legfontosabb, az üzleti tervnek kisebb szerepe van. Azon túl, hogy a KFK támogatásával számos ilyen diákvállalkozás jön létre, a projektnek tovagyưrüző hatása van, a programban részt vevő hallgatók (alumni) példája pozitívan hat társaikra. A mentori tapasztalatokat sikeresen használjuk fel az oktatás során, ezeket a vállalkozásokat állítva iskolapéldaként kurzusainkat hallgató diákjaink számára. A legjobb csapatok rendszeresen beszámolnak hallgatótársaiknak tapasztalataikról, a kihívásokról, melyekkel szembesültek. Az ifjú vállalkozók egymással is kapcsolatot tartanak, megosztják élményeiket, sốt arra is volt már példa, hogy egymással kötöttek üzletet (Csapó, 2007b).

Munkatársaink egy része aktív szerepet vállalt az Ifjú Vállalkozók Magyarországi Szövetsége (YES Hungary) megalakításában, mely szervezet alapító tagjai között vannak a HSM- programunk legsikeresebb vállalkozói is. Az itt megismert fiatal vállalkozók szívesen jönnek előadásokra, mutatnak pozitív példát a hallgatóknak. Hallgatói visszajelzések ugyanis azt támasztják alá, hogy a diákok sokkal inkább azonosulni tudnak egy náluk csupán néhány évvel idősebb fiatal esetével, mint a náluk sokkal idôsebb vállalkozókéval. 
Újabb lehetôségeket fog a központ számára jelenteni, ha az egyetem Regionális Egyetemi Tudásközpontja megkezdi tényleges múködését, az elsố kutatási eredmények a piacon értékesíthetók lesznek, vagy ezek létrejövő spin-off vállalkozások alapját fogják képezni.

A nemzetközi gyakorlat átvételét, megismerését segíti a központ vezetésével létrehozott ERENET hálózat, mely a környező országok vállalkozáskutatással és oktatással foglalkozó felsőoktatási intézményeinek oktatóit fogja össze. Az ERENET keretében szervezett kutatási projektek, múhelyviták mind-mind hozzájárulnak a KFK tudásbázisának növeléséhez.

\section{Zárógondolatok}

Mint a fentiekben láthattuk a Corvinus Egyetem példáján, számos olyan, Amerikában megismert, a vállalkozásoktatásban alkalmazott módszer van, melyet itthon is sikerrel tudtunk alkalmazni. A zárógondolatok között továbbfejlesztési lehetóségeket fogalmazunk meg, illetve kijelölünk néhány olyan feladatot, melyet a jövốben meg kellene oldanunk a hatékonyabb vállalkozásoktatás érdekében.

A három amerikai egyetem általunk megismert vállalkozásoktatási programjának közös jellemzője, hogy elsősorban nem konkrét ismeretek megtanítására törekednek, hanem, mint Mihályi Ildikó is írta, ,a vállalkozói viselkedésmód, a jellegzetes üzleti magatartás elemeit oktatják a résztvevók számára" (Mihályi, $2001)^{5}$. Kisebb hallgatói létszámok esetén lehetôség lenne az oktatás ebbe az irányba való továbbfejlesztésére. Hasonlóan fontos lenne, ha egy-egy órán nemcsak közgazdászhallgatók lennének, hanem az egyetemünk természettudományi képzésére járó diákokat is be lehetne csalogatni ${ }^{6}$. Ekkor a különbözô hátterú diákok még izgalmasabb üzleti ötletekkel állnának elő. Ez a BCE-n a „Bologna konform” BA szakok beindulásának köszönhetően hamarosan megvalósulhat.

Meg kellene fogadnunk David F. Kuratko (2004) tanácsát is, aki arra hívja fel a figyelmet, hogy vállalkozási ismereteket olyan oktatók tudnak hatékonyan tanítani, akik legalább szemléletüket tekintve maguk is vállalkozók. Az oktatókkal szemben elvárás az innovativitás, az újra való törekvés, melynek egyik megjelenési formája, hogy képesek legyenek újfajta oktatási módszerek alkalmazására, a technologia kezelésére. Kuratko erre példaként a videókonferenciát és a videoesettanulmányok felhasználását hozza fel.

Mint az Európai Unió „A vállalkozói készségek előmozdítása az oktatás és a tanulás révén" c. közleménye is megfogalmazza, „Az esettanulmányok és egyéb interaktív tanítási módszerek, illetve az üzletemberek tanulási folyamatba való bevonásában rejlő lehetóségek messze nem kiaknázottak" (Európai Közösségek, 2006). Több felsôoktatási intézményen átfogó üzletiterv-versenyeket kellene hirdetni, melyek kiváló alkalmat teremthetnének arra is, hogy a hallgatók befektetốkkel találkozzanak.

A legtöbb hazai felsőoktatási intézménynél a vállalkozásoktatás továbbfejlesztése érdekében fontos lenne az üzleti szférával, ipari partnerekkel erôteljesebb kapcsolat kialakítására törekedni. Ennek egyik eszközét jelenthetik a Kooperációs Kutatási Központok, az Egyetemi Tudásközpontok. A Corvinus esetében ezt az Élelmiszertudományi Egyetemi Tudásközponton keresztül lehetne megvalósítani, ahol a KFK azt a feladatot vállalta fel, hogy segít az itt létrejövő kutatási eredményekre épító spin-off vállalkozások elindításában. A tudásközpont keretei között fokozottabban kellene az ipari kutatások piacán megjelenni (melyért a megbízók innovációs járulékkal fizethetnek). Ezek a kutatások lehetôvé tennék egyrészt a kollégák ismereteinek folyamatos bővítését, frissítését, másrészt az eredményeket az oktatásban bemutatva az órákat még színesebbé, érdekesebbé lehet tenni. A doktoranduszok empirikus kutatási eredményei lehetôséget nyújtanak arra, hogy a központ a tanácsadási területen is megjelenjen, a megszerzett tudást megpróbálja a piacon is értékesíteni.

\section{Lábjegyzet}

${ }^{1}$ A GEM a vállalkozói aktivitás mérésének átfogó mutatójaként a „Korai Fázisú Vállalkozói Aktivitási Mutatót” (KFV) alkalmazza. A KFV lényegében a 18-64 éves felnőtt népesség azon százalékának az összege, akiknek a születoóben lévő vállalkozása (valamit tettek a közeli cégalapítás érdekében), illetve akinek fiatal vállalkozása (42 hónapnál nem idôsebb) van (Szerb, 2005, 11. o., illetve Szerb et al., 2006).

2 Ennek előzménye volt a „Vállalkozásbarát Egyetem - Vállalkozásképes Hallgatók projekt, melyról számos publikációban beszámoltunk. Bővebben ld. Csapó et al. (2005), Szirmai és Csapó (2006) illetve Csapó (2007b).

${ }^{3} \mathrm{Ez}$ a gondolat már a hazai felsőoktatásban is megjelent: „Entrepreneur uses other people's money” hallhatják a Kisvállalkozások indítása és múködtetése c. tárgy keretében a Budapesti Corvinus Egyetemen Vecsenyi Jánostól a hallgatók. Forrás: Vecsenyi (2006b).

4 A fogalom az angol „social enterprise” szó magyar fordítása. „A szociális vállalkozás elsődlegesen szociális célokkal bíró szervezet, mely nyereségét fóként ettól a céltól - s nem a tulajdonosok vagy részvényesek profitmaximalizálási szempontjait figyelembe véve - vezérelve fekteti be újra üzleti tevékenységének vagy a közösség fejlesztésének érdekében" (Csoba, 2006).

5 A kompetenciafejlesztés fontosságára hívja fel a figyelmet többek között Tibor Ágnes (2006) közelmúltban megjelent cikke is.

${ }^{6}$ Ezt már néhány hazai egyetem (pl. Miskolci Egyetem) megvalósította (ld. Szerb et al., 2006). 


\section{Felhasznát irodalom}

Csapó K. - Petheó A. - Szirmai P. (2005): Bepörög vagy kipörög? Figyelő, 49. évf., 49. sz., 54-55. o.

Csapó K. (2007a): Gyorsan növekvố vállalkozások - A magyarországi helyzetkép. PhD-értekezéstervezet. Budapesti Corvinus Egyetem

Csapó K. (2007b): Vállalkozásoktatás diákvállalkozásokon keresztuil - tapasztalatok a Budapesti Corvinus Egyetemról. Vezetéstudomány, 38. évf., 4. sz., 30-42. o.

Csapó K. (2007c): Csoportos munka - csoportos értékelés. Közgazdász, 48. évf., 4. sz.

Csoba J. (2006): A szociális gazdaság szerepe a foglalkoz tatásbővítésben. Előadás a FORTE Program keretében 2006. 03. 17-én, letöltve: http://hefopgordiusz.web. services.hu/forte/kepzes/a_szocialis_gazdasag_es_ foglalkoztatasbovites.ppt 2007.08.05-én 18:41-kor

Cruikshank, J.L. (2005): Shaping the Waves - A History of Entrepreneurship at Harvard Business School. Harvard Business School Press, Boston, MA

Davidsson, P. (1995): Determinants of entrepreneurial intentions. Konferenciaelőadás, IX. RENT Workshop, 1995.11.23-24, Piacenza, Olaszország

De, D. (2001): Fostering Entrepreneurship in Europe. In: Lundström, A., Stevenson, L. Entrepreneurship Policy for the Future: Volume 1 of the Entrepreneurship for the Future Series, pp. 107-130. Swedish Foundation of Small Business Research

Engel, J.S. - Charron, D. (2006a): Technology Entrepreneurship Education. UC Berkeley, CA

Engel, J. - Charron, D. (2006b): Technology Entrepreneurship Education - Theory to Practice. Intel - Berkeley vállalkozásoktatási szeminárium. Budapest, 2006. november 22-23.

European Commission (2003c): Observatory of European SMEs 2003, No. 7

European Commission (2004b): Helping to create an entrepreneurial culture - A guide on good practices in promoting entrepreneurial attitudes and skills through education, Luxemburg

Európai Közösségek (2006): A közösség lisszaboni programjának végrehajtása: A vállalkozói készségek előmozdítása az oktatás és a tanulás révén. COM(2006) 33 végleges. Letöltve: http://eur-lex.europa.eu/LexUriServ/ site/hu/com/2006/com2006_0033hu01.pdf 2007. 08. 20-án 22:07-kor

Flash Eurobarometer 134, „Entrepreneurship”, November 2002.

Flash Eurobarometer 160, „Entrepreneurship”, June 2004

Gorman, G. - Hanlon, D. - King, W. (1997): Some Research Perspectives on Entrepreneurship Education, Enterprise Education, and Education for Small Business Management: A ten-year literature review. International Small Business Journal, Vol. 15, No. 3, pp. 56-77.

HBS (2006): Entrepreneurship Program at Harvard Business School Wins Top Award. Letöltve: http://www.hbs.edu/about/news/ 012204_entrepreneurship.html 2006. 09. 28-án 10:02-kor
Horváth M. - Vertetich Á. (2007): Vállalkozói kultúra - egy lehetséges magyarázat Európa lemaradására. Köz-gazdaság, II. évf., 2. sz., 203-205. o.

ISBA (2004): Making the Journey from Student to Entrepreneur: A Review of the Existing Research into Graduate Entrepreneurship. ISBA, letöltve: http://www.ncge. org.uk/communities/files/biblio589.pdf 2006. 10. 17-én 22:25-kor

Jamieson, I. (1984): Schools and Enterprise. In: Watts, A. G., Moran, P. (eds.): Education for Enterprise. CRAC, Ballinger, Cambridge, pp. 19-27.

Kiss A. - Bod E. - Domonkos G. - Ilyés M. - Knáb M. -Wolf $P$. (2005): A vállalkozók képzése, vállalkozási ismeretek oktatása EU-összehasonlításban és a továbbképzésre (fejlesztésre) vonatkozó javaslatok. Piacgazdaság Alapítvány

Kuratko, D. F. (2003): Entrepreneurship Education: Emerging Trends and Challenges for the $21^{\text {st }}$ Century. 2003 Coleman Foundation White Paper Series for the U.S. Association of Small Business \& Entrepreneurship. Letöltve: http://www.usasbe.org/pdf/CWP-2003-kuratko.pdf 2007. 04. 12-én 15:12-kor

Kuratko, D. F. (2004): Entrepreneurship Education in the 21st Century: From Legitimization to Leadership. A Coleman Foundation White Paper, USASBE National Conference, January 16, 2004. Letöltve: http://sbaer. uca.edu/research/usasbe/2004/pdf/01.pdf 2007. 08. 20án 22:21-kor

Matlay, H. (2005): Entrepreneurship education in UK business schools: Conceptual, contextual and policy considerations. Journal of Small Business and Enterprise Development. Vol. 12, No. 4, pp. 627-643.

Mihályi I. (2001): Vállalkozási ismeretek oktatása Európában. Új Pedagógiai Szemle, 5. évf., 12. sz., 81-89. o.

Penaluna, A. - Penaluna, K. (2006): Business Paradigms in Einstellung: Entrepreneurship Education, A Creative Industries Perspective. NCGE Working Paper Series, http://www.ncge.org.uk/communities/files/biblio740. pdf letöltve: 2006. 10. 17-én 9:21-kor

Román Z. (2006): A vállalkozás oktatása a felsőoktatásban. Vezetéstudomány, 37. évf., 1. szám, 2-9. o.

Stevenson, H. - Gumpert, D. (1985): The Heart of Entrepreneurship. Harvard Business Review, Vol. 63, No. 2, pp. 85-94.

Szerb L. - Zoltan J. Acs - Varga A. - Ulbert J. - Bodor É. (2004): Az új vállalkozások hatásai nemzetközi öszszehasonlításban. A Global Entrepreneurship Monitor nemzetközi kutatás legfontosabb eredményei a 20012003-as időszakban. Közgazdasági Szemle, 51. évf., 78. sz., 679-98. o.

Szerb L. (szerk.) (2005): Vállalkozásindítás, vállalkozói hajlandóság és a vállalkozási környezeti tényezôk alakulása Magyarországon a 2000-es évek elsố felében. Pécsi Tudományegyetem, Pécs

Szerb L. - Márkus G. (2006): Nemzetközi felmérés az egyetemi hallgatók vállalkozói aktivitásáról: Magyarország 2006. Kutatási jelentés, Pécsi Tudományegyetem 
Szirmai P. - Csapó K. (2006): Gyakorlati vállalkozásoktatás - Diákvállalkozások támogatása a Budapesti Corvinus Egyetemen. Új Pedagógiai Szemle, 10. évf., 4. sz., 7283. 0.

Tibor Ágnes (2006): Kapcsolatépítés - segédanyag középiskolai tanároknak a kompetencia fejlesztéséhez. EDUNET, Budapest

Timmons, J. A. - Spinelli, S. (2007): New Venture Creation - Entrepreneurship for the 21st Century. 7th Edition. McGraw-Hill, New York
Vecsenyi J. (2006a): Harvardi tapasztalatok és ihletések. Kézirat, BCE-KFK

Vecsenyi J. (2006b): Felkészülés a vállalkozásra. Előadás a Kisvállalkozások indítása és múködtetése c. tárgy keretében a Budapesti Corvinus Egyetem hallgatóinak 2006. szeptember 18-án

Cikk beérkezett: 2007. 6. hó

Lektori vélemény alapján átdolgozva: 2007. 8.

\section{E SZÁMUNK SZERZÖI}

Csapó Krisztián, egyetemi tanársegéd, Budapesti Corvinus Egyetem; Dr. Gajduschek György, egyetemi docens, Károli Gáspár Református Egyetem; Harangozó Gábor, egyetemi tanársegéd, Budapesti Corvinus Egyetem; Konczosné dr. Szombathelyi Márta, Ph.D., egyetemi docens, Széchenyi István Egyetem; Dr. Kunos István, egyetemi docens, Miskolci Egyetem; Lakatos Orsolya, Ph.D. hallgató, Miskolci Egyetem; Dr. Losoncz Miklós, kandidátus, kutatásvezető, GKI Gazdaságkutató Zrt. 